\title{
Relict landslides, gullies and geoheritage sites - Băiceni village
}

\author{
Mihai Niculiță, Mihai Ciprian Mărgărint \\ Department of Geography, Faculty of Geography and \\ Geology \\ Alexandru Ioan Cuza University of Iaşi \\ Iaşi, Romania \\ mihai.niculita@uaic.ro,margarint.ciprian@yahoo.com
}

\author{
Ionuț Cristea \\ Department of Geography \\ Faculty of Geography and History \\ Ştefan cel Mare University of Suceava \\ icristea@atlas.usv.ro
}

\section{BĂICENI GEOHERITAEGE SITE}

Cucuteni - Cetăţuia site is located at the edge of the Laiu plateau, on a promontory cut by a gully, and is bounded on north, east and south sides by deep-seated landslide scarps [1]. The main inhabitation of the settlement is attributed to Cucuteni A. This settlement is related to the Băiceni Dâmbul Morii settlement, located downstream, at the base of the hillslope, on the relict landslide deposits, between Recea and Morii rivers (Fig. 1). The site was populated in the Cucuteni $\mathrm{A}$ and $\mathrm{AB}$ phases. The complex landslides that affect the north, west and south hillslopes are retrogressive landslides which generated the slide of the sandstone layer over the underlying claystones and sands (Fig. 2).

\section{BĂICENI LANDSLIDE}

The complex landslide from Băiceni village is a relict landslide with a Lower Holocene or Upper Pleistocene age [2]. The genesis of the landslide is related to the retrogressive model of slope evolution [Fig. 2] identified by $[1,2,3]$, and used by the chalcolithic populations to establish their settlements [1].

The landslide body is covered by layers of buried paleosoils (Fig. 3 a, b) which show intense hillslope evolution and argue the old age of the initial movement.

The stratigraphy of the landslide toe, which cover the floodplain deposits of the Băiceni valley, was interpreted using a 2D ERT scan (Fig. 4). [4].

The Băiceni landslide was argued as a geoheritage site by

\section{MORII GULLY}

The Băiceni landslide is incised by two streams, which evolved (Fig. 1, 2) through regressive erosion. In the last 100 years their channel heads evolved as gullies, the Morii gully showing continuous activity from the ' 70 (Fig. 5, 6) [5].

\section{ACKNOWLEDGMENT}

We are grateful to Prut-Bârlad Water Administration who provided us with the LIDAR data. We have used the computational facilities given by the infrastructure provided through the POSCCE-O 2.2.1, SMIS-CSNR 13984-901, No. 257/28.09.2010 Project, CERNESIM (L4).

\section{REFERENCES}

[1] M. Niculiță., M.C. Mărgărint, and M. Santangelo, "Archaeological evidence for Holocene landslide activity in the Eastern Carpathian lowland”, Quaternary International, vol. 415, pp. 175-189, 2016.

[2] M. Niculiță., M.C. Mărgărint, and M. Santangelo, "Pleistocene landslides in the Moldavian Plateau, Eastern Romania", Georeview, vol. 26, $\quad$ no. 2 , $\quad$ pp. 2016. http://dx.doi.org/10.4316/GEOREVIEW.2016.0.0.341

[3] M.C. Mărgărint and M. Niculiță, "Landslide type and pattern in Moldavian Plateau, NE Romania", in Landform Dynamics and Evolution in Romania, M. Rădoane and A. Vespremeanu-Stroe, Eds. Springer, 2017, pp. 271-304. doi:10.1007/978-3-319-32589-7_12

[4] M. Niculiță. and M.C. Mărgărint, "Landslides and fortified settlements as valuable geoheritage sites in the Moldavian Plateau, NorthEastern Romania, Geoheritage (submitted).

[5] Gh. Romanescu, and I.C. Nicu, "Risk maps for gully erosion processes affecting archaeological sites in Moldavia, Romania", Zeitschrift für Geomorphologie, vol. 58, no. 4, pp. 509-523, 2014. 


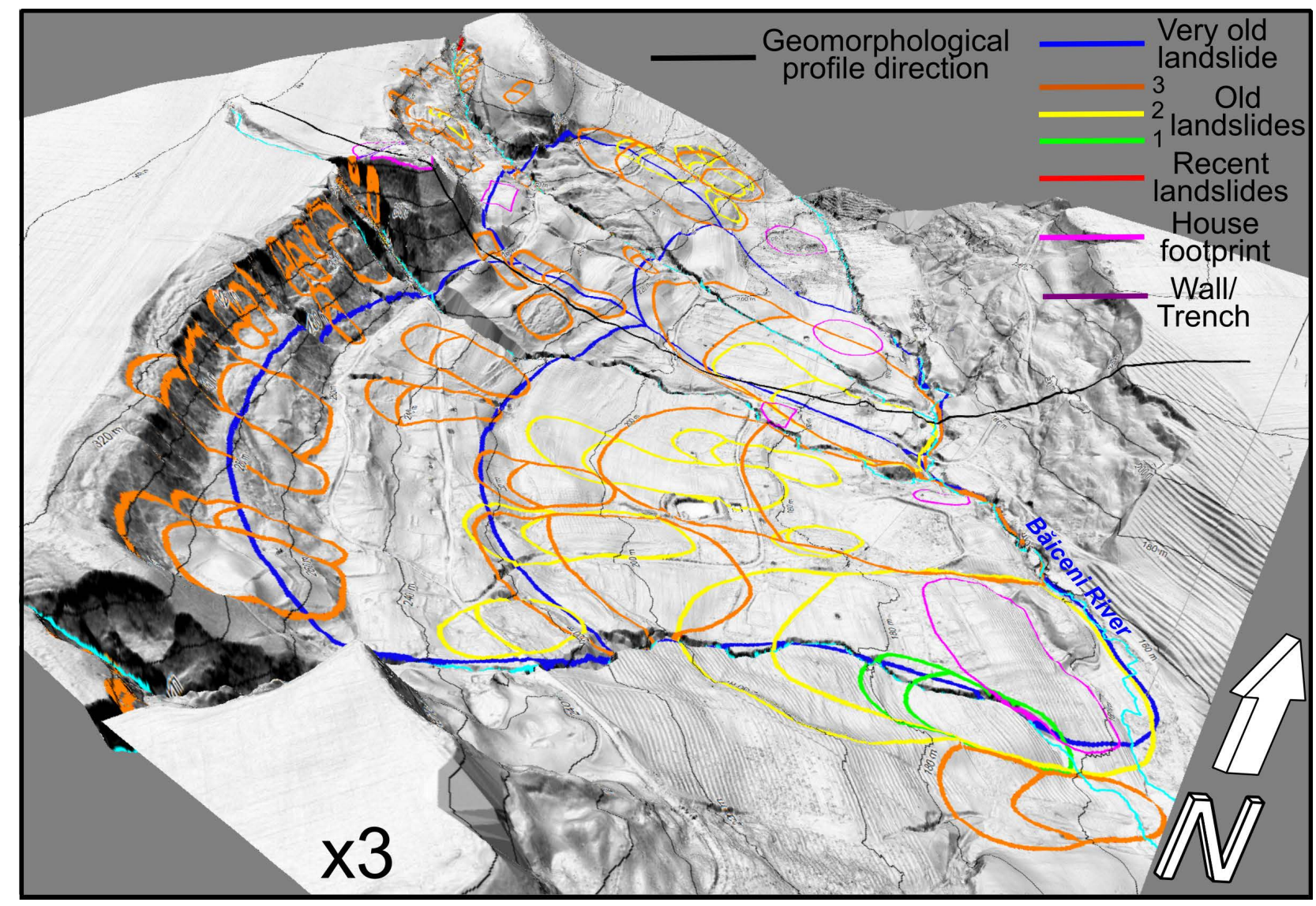

Fig. 1. 3D view of the Băiceni geoheritage site [3]: LiDAR shaded image and the landslide inventory from [1]
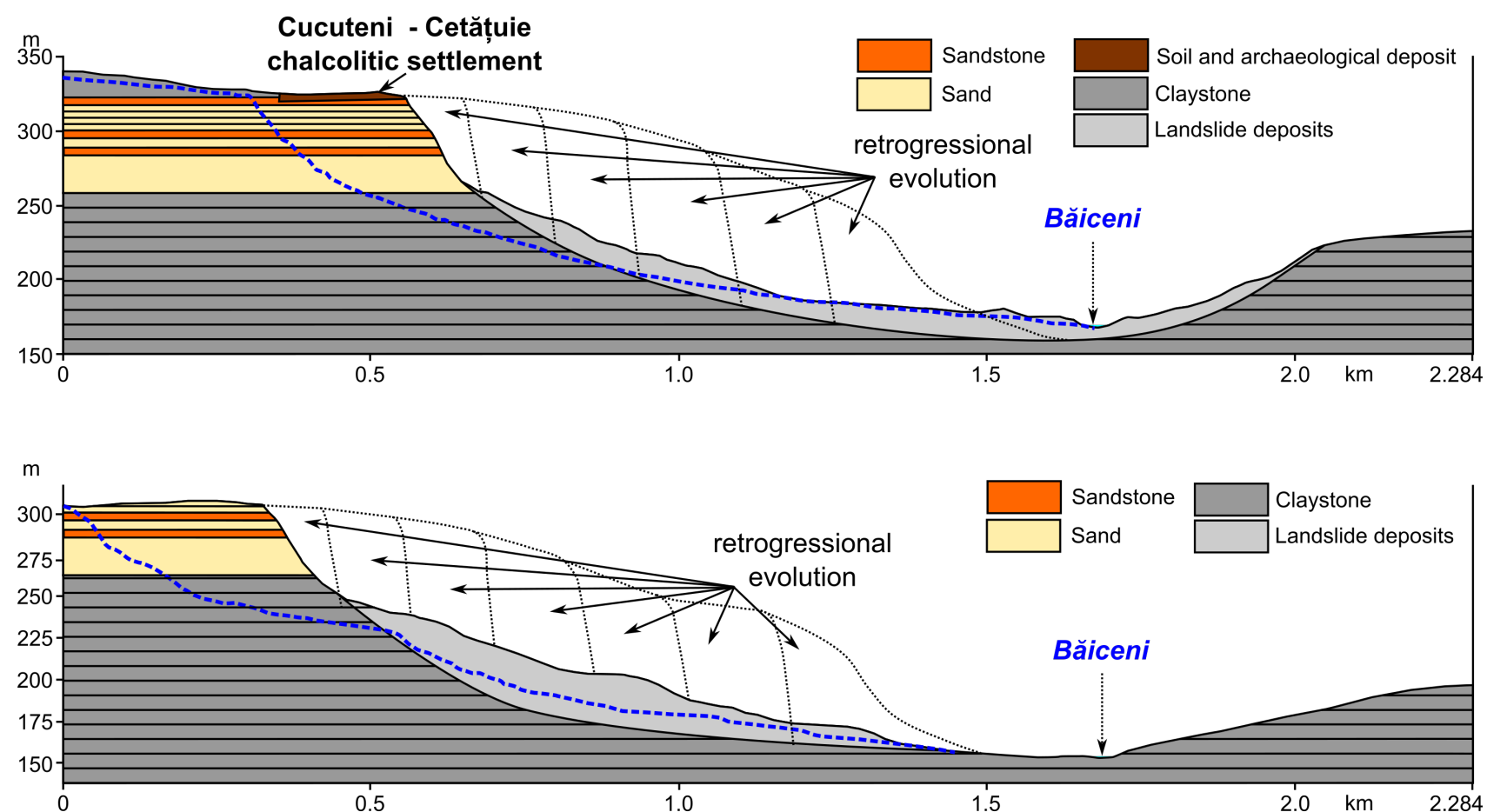

Fig. 2. Geomorphological interpretation of the Băiceni geoheritage site retrogressive mass movement model [2]. 

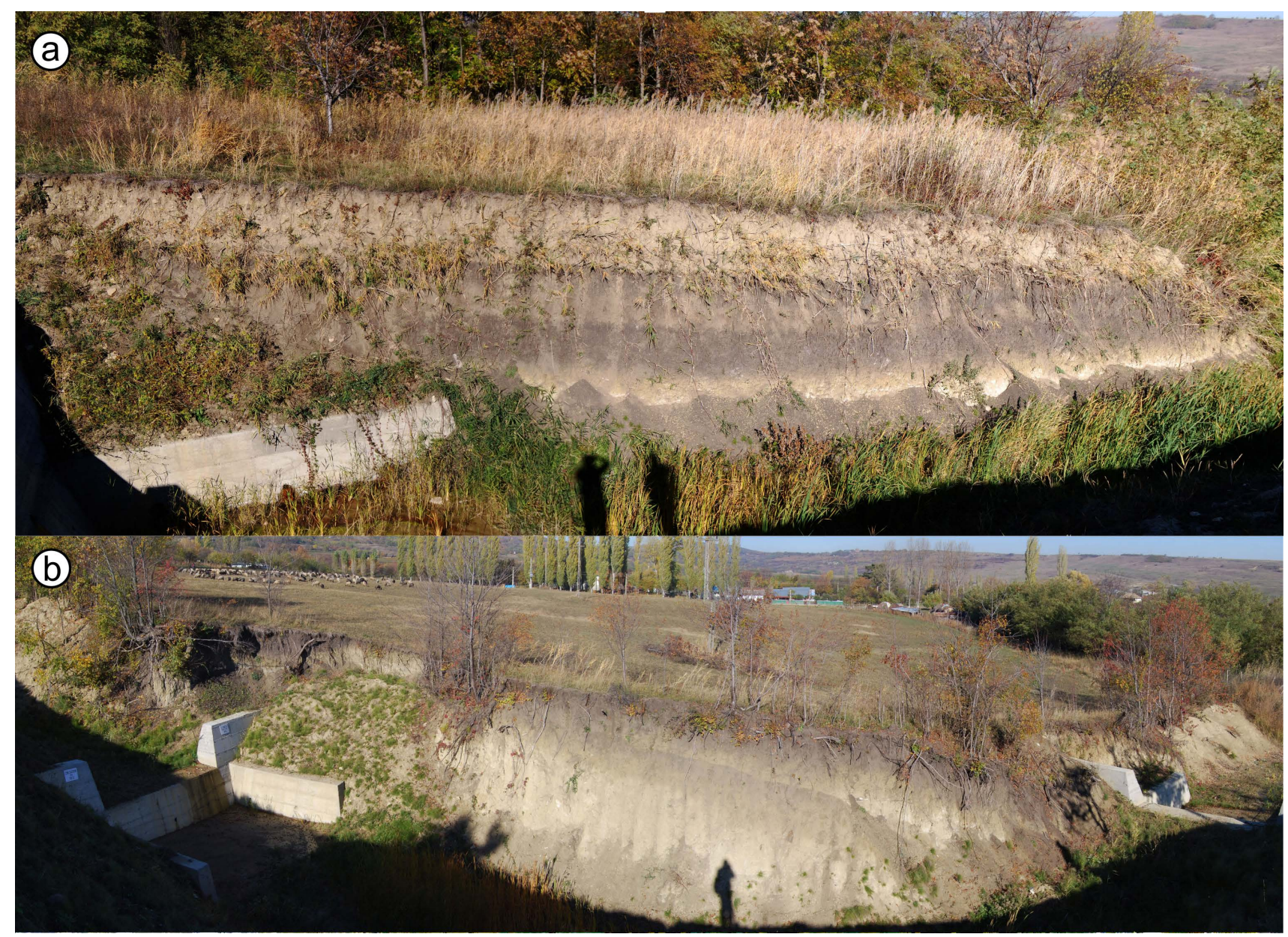

Fig. 3. Stratigraphy of the Băiceni landslide body cover, revealed in the Morii river bank showing buried soils (the location of the photos is shown in Fig. 1 - red a and b)

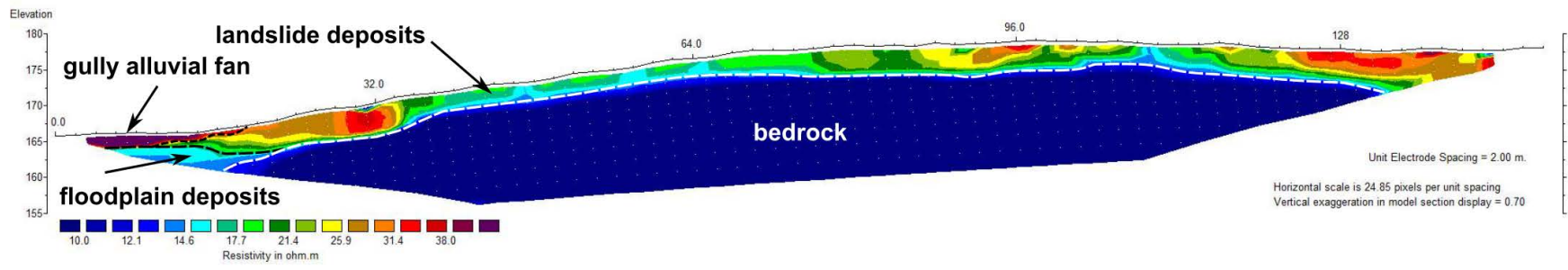

Fig. 4. Băiceni geoheritage site stratigraphy interpreted from 2D ERT. 


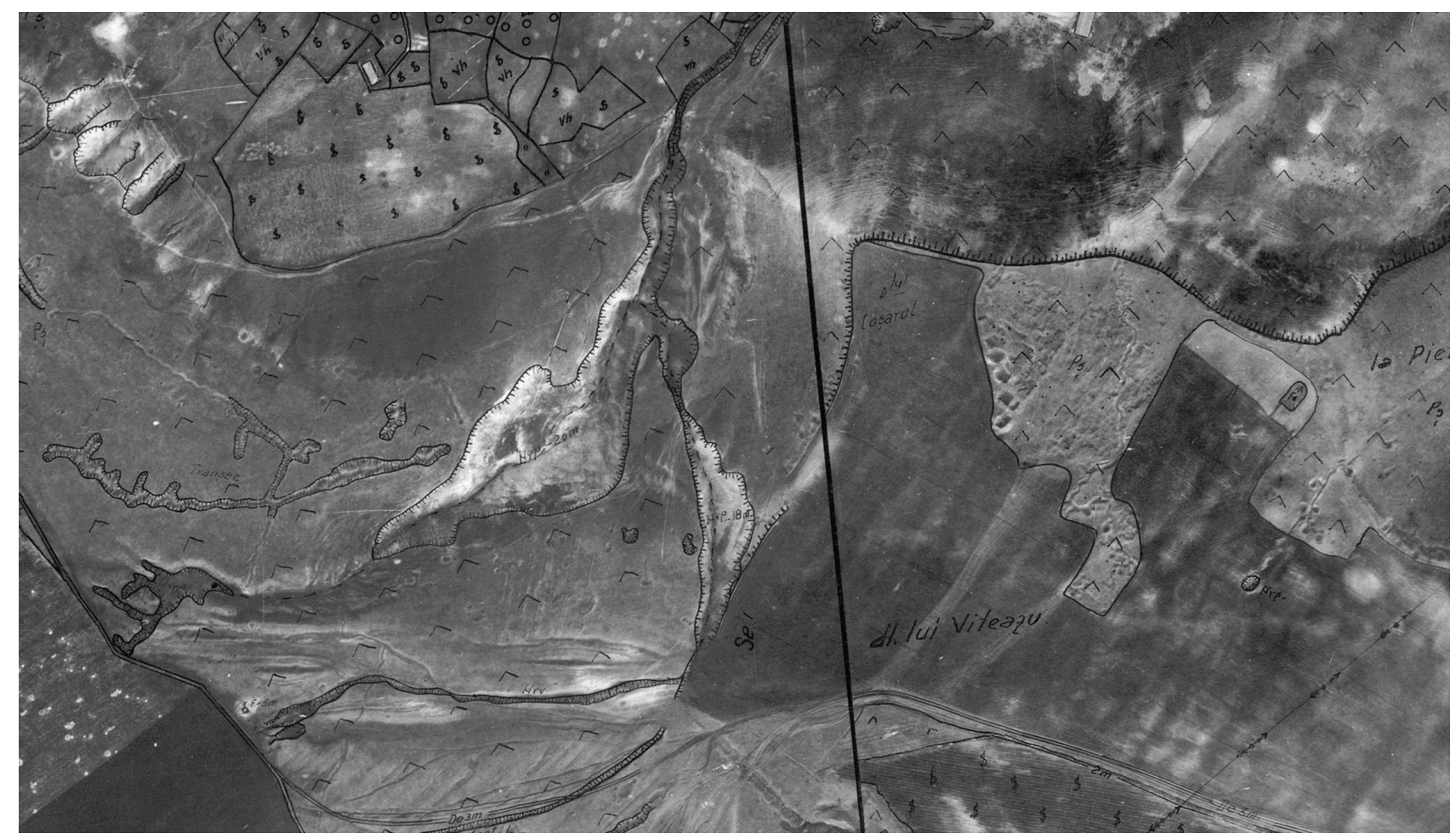

Fig. 5. Aerial image of the Morii gully (1971).

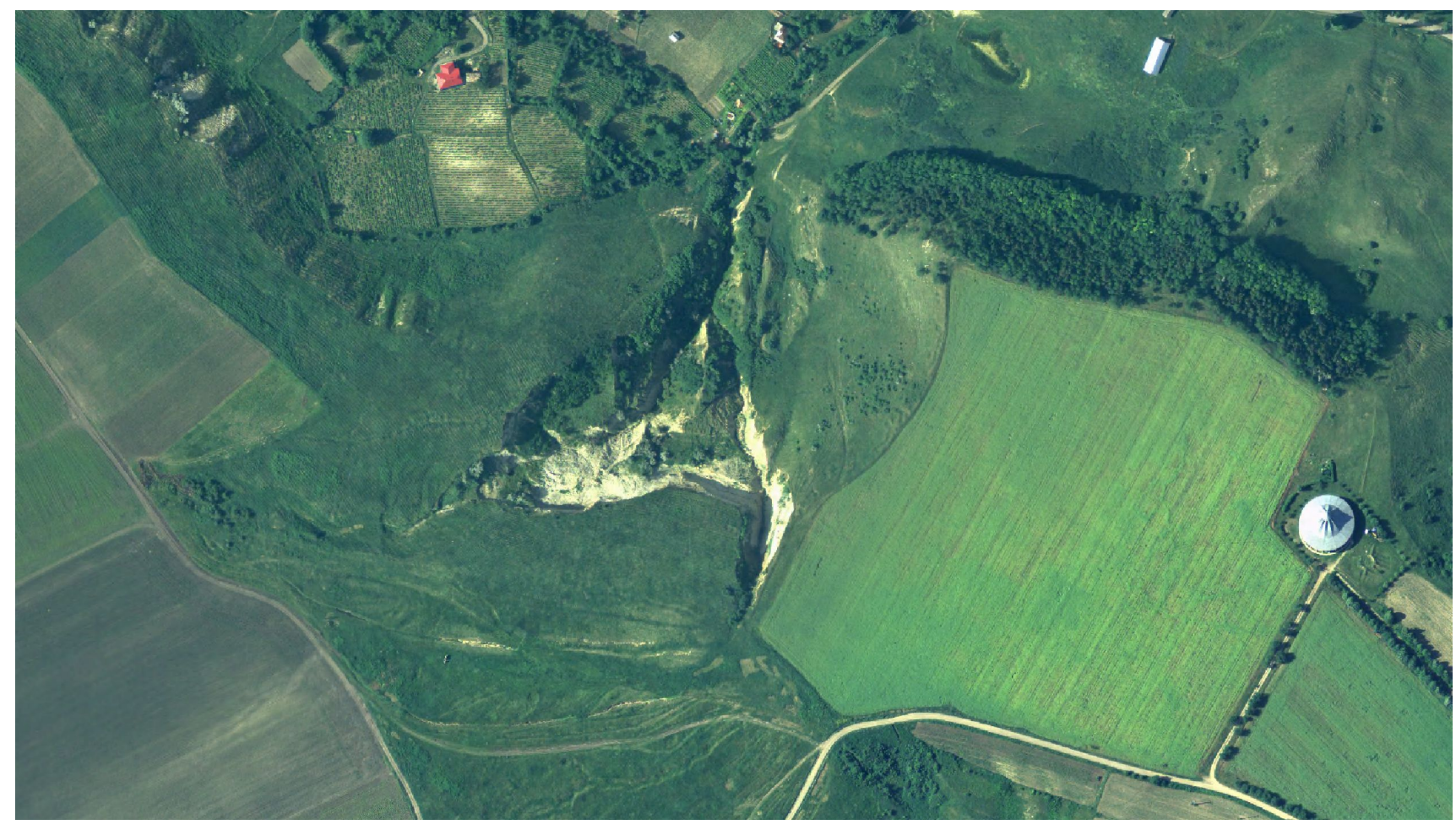

Fig. 6. Aerial image of the Morii gully (2008). 